\title{
PEMANFAATAN WADUK BENING/ WIDAS SEBAGAI LOKASI PEMBANGKIT LISTRIK TENAGA SURYA (PLTS)
}

\author{
Herwangga Satria Permana ${ }^{1)}$, Rintis Hadiani ${ }^{2}$, Solichin ${ }^{2)}$ \\ ${ }^{1}$ Mahasiswa Prodi Teknik Sipil, Fakultas Teknik, Universitas Sebelas Maret Jl. Ir. Sutami 36A, Surakarta \\ ${ }^{2)}$ Pengajar Prodi Teknik Sipil, Fakultas Teknik, Universitas Sebelas Maret Jl. Ir. Sutami 36A, Surakarta \\ Email: herwanggasp@gmail.com
}

\begin{abstract}
Electricity is a basic requirement in carrying out activities. However, over time, the electricity needs to increase but the availability of electricity is still stagnant. So that the necessary innovation of electricity generation. Solar power plants (PLTS) can be a solution to this problem. PLTS tends to require extensive land, therefore the idea of utilizing the reservoir as a PLTS location. In this penelitin selected Reservoir Bening / Widas as PLTS location. The calculation of the extent of the permit puddle needs to be done to find out how much PLTS design can be built. Furthermore, it is necessary to calculate the energy generated as well as economic feasibility analysis. The results of this study indicate that the area of permit inundation in the Bening / Widas Reservoir is $944893 \mathrm{~m} 2$ and PLTS which can be built as many as 20 modules with a design area of 1 module PLTS is $8000 \mathrm{~m}^{2}$. The energy produced by 20 PLTS modules within 1 year is $19668.52 \mathrm{MWh}$.

Keywords: Solar Power Plant, Bening/Widas Reservoir, energy.
\end{abstract}

\begin{abstract}
ABSTRAK
Listrik merupakan kebutuhan pokok dalam menjalankan aktivitas. Namun seiring berjalannya waktu, kebutuhan listrik semakin naik namun ketersediaan listrik masih stagnan. Sehingga diperlukan adanya inovasi pembangkitan listrik. Pembangkit listrik tenaga surya (PLTS) bisa menjadi solusi untuk masalah ini. PLTS cenderung membutuhkan lahan yang luas, oleh sebab itu muncullah ide pemanfaatan waduk sebagai lokasi PLTS. Dalam penelitin ini dipilih Waduk Bening/Widas sebagai lokasi PLTS. Perhitungan luas genangan ijin perlu dilakukan untuk mengetahui berapa luas desain PLTS yang dapat dibangun. Selanjutnya perlu dihitung pula energi yang dihasilkan serta analisis kelayakan ekonomi. Hasil dari penelitian ini menunjukkan bahwa luas genangan ijin di Waduk Bening/Widas adalah $944893 \mathrm{~m} 2$ dan PLTS yang dapat dibangun sebanyak 20 modul dengan luas desain PLTS 1 modul adalah $8000 \mathrm{~m}^{2}$. Energi yang dihasilkan oleh 20 modul PLTS dalam waktu 1 tahun adalah sebesar 19668,52 MWh.

Kata kunci: Pembangkit Listrik Tenaga surya, Waduk Bening/Widas, energi.
\end{abstract}

\section{PENDAHULUAN}

Indonesia adalah sebuah negara berkembang, setiap tahunnya selalu ada inovasi baru disemua sektor. Setiap sektor tersebut, membutuhkan pasokan energi listrik yang besar. Namun pada kenyataannya, ketersediaan energi listrik di Indonesia masih sangat sedikit. Bahkan di daerah-daerah terpencil ketersediaan energi listrik belum ada, hal ini mengindikasikan bahwa pemerataan distribusi energi listrik masih belum merata dan ketersediaannya masih sangat kurang.

PLTA yang gencar dibangun tetap tidak bisa menutup kebutuhan listrik tersebut. Oleh sebab itu harus ada inovasi baru dibidang pembangkitan. Indonesia terletak pada koordinat $6^{\circ} \mathrm{LU}-11^{\circ} 08^{\prime} \mathrm{LS}$ dan $95^{\circ} \mathrm{BT}-141^{\circ} 45^{\prime} \mathrm{BT}$. Berdasarkan koordinat tersebut, Indonesia berada tepat pada garis khatulistiwa. Letak tersebut sangatlah menguntungkan karena dengan begitu Indonesia memiliki sumber energi surya yang berlimpah. Energi surya yang memasuki atmosfer memiliki kerapatan daya rata-rata sebesar $1,2 \mathrm{~kW} / \mathrm{m} 2$, namun hanya sebesar $560 \mathrm{~W} / \mathrm{m} 2$ yang diserap bumi. Berdasarkan angka di atas, maka energi surya yang dapat dibangkitkan untuk seluruh daratan Indonesia yang mempunyai luas \pm 2 juta km2 adalah sebesar 5.108 MW (I G N Nitya S, dkk., 2005).

Pembangkit Listrik Tenaga Surya (PLTS) menjadi inovasi baru dan solusi bagi permasalahan kebutuhan listrik Indonesia. Energi radiasi matahari dirubah menjadi energi listrik dengan mempergunakan pembangkit listrik tenaga surya atau disebut juga teknologi photovoltaic yang terbuat dari bahan semi konduktor, yang disebut solar cell (Hasnawiya H, 2012).

Pembangunan PLTS bisa dalam skala kecil dan bisa juga dalam skala besar. Pembangunan ini disesuaikan dengan kebutuhan. Pembangunan PLTS dalam skala kecil biasanya digunakan untuk memenuhi kebutuhan listrik perumahan atau sering disebut solar home system (SHS), pompa air, televisi komunikasi, dll. Sedangkan pembangunan PLTS dalam skala besar bisa digunakan untuk memenuhi kebutuhan listrik 1 desa. Namun, semakin besar daya yang dihasilkan maka semakin besar pula kebutuhan lahan untuk pembangkit listrik. 
Sistem PLTS terapung bisa menjadi salah satu solusi untuk mengatasi kebutuhan lahan. Salah satu tempat yang efektif untuk pembangunan PLTS terapung ini adalah waduk. Waduk merupakan suatu bangunan air yang berfungsi untuk menampung air yang digunakan pada saat debit rendah. PLTS ini bisa kita apungkan di tampungan/ permukaan air waduk.

Penelitian ini dilakukan di Waduk Bening/ Widas, Kecamatan Saradan, Kabupaten Madiun. Tempat ini dipilih karena mempunyai potensi yang besar untuk pembangunan PLTS terapung. Untuk mendesain PLTS diatas waduk, kita harus mengetahui terlebih dahulu berapa luas permukaan waduk pada elevasi muka air yang sering terjadi. Tidak semua luas waduk dapat dibangun struktur diatasnya, oleh sebab itu kita harus mencari luas genangan ijin. Luas genangan ijin inilah yang menjadi acuan berapa luas desain PLTS yang dapat dirancang. Sebelum membangun PLTS dalam skala besar, harus dilakukan kajian terlebih dahulu mengenai daya yang dihasilkan PLTS. Penelitian ini mengkaji berapa besar daya yang akan dihasilkan dari desain PLTS yang dirancang diatas Waduk.

Penelitian ini dilakukan dengan tujuan untuk mendapatkan luas desain PLTS yang efektif yang dapat diterapkan di Waduk Bening/Widas serta mengetahui berapa daya yang dihasilkan dari desain tersebut. Peneltian ini diharapkan dapat dikembangkan lebih dalam dan dijadikan acuan dalam mendesain PLTS terapung di waduk.

\section{LANDASAN TEORI}

\section{Uji Validitas Data Hujan}

Sebelum dilakukan analisis data hujan, maka terlebih dahulu harus dilakukan uji validitas data hujan atau uji kepanggahan. Penelitian ini menggunakan uji validitas Kurva Massa Ganda dalam menentukan kepanggahan data. Metode ini menggunakan grafik dalam penentuan kepanggahannya. Apabila secara visual grafik uji konsistensi memperlihatkan garis lurus, maka data bisa dikatakan panggah. Apabila grafik tidak lurus, maka harus dilakukan koreksi data hujan dengan mengalikan data hujan dengan faktor koreksi sebelum atau sesudah grafik patah.

\section{Hujan Wilayah}

Metode Thiessen memperhitungkan bobot dari masing-masing stasiun yang mewakili luasan disekitarnya. Metode ini digunakan apabila penyebaran stasiun hujan didaerah yang ditinjau tidak merata. Hitungan curah hujan rerata dilakukan dengan memperhitungkan daerah pengaruh dari tiap stasiun (Soemarto, 1999).

$\bar{P}=\frac{P_{1} A_{1}+P_{2} A_{2}+\ldots+P_{n} A_{n}}{A_{1}+A_{2}+\ldots+A_{n}}$ dengan:

$\overline{\mathrm{P}}$

$\mathrm{P} 1, \mathrm{P} 2, \ldots ., \mathrm{Pn}$

$\mathrm{A} 1, \mathrm{~A} 2, \ldots ., \mathrm{An}$

$\mathrm{n}$
: curah hujan rata-rata DAS (mm);

: curah hujan di stasiun hujan $1,2, \ldots ., \mathrm{n}(\mathrm{mm})$;

: luas areal poligon dari stasiun hujan $1,2, \ldots ., \mathrm{n}(\mathrm{km} 2)$;

: banyaknya stasiun hujan.

\section{Distribusi Sebaran}

Data hidrologi harus diuji kesesuaiannya dengan parameter statistik untuk mengetahui jenis distribusi sebaran yang dapat digunakan. Jenis distribusi sebaran yang digunakan pada penelitian ini adalah Gumbell dan Log Pearson Type III, diambil hasil perhitungan yang terbesar.

\section{Uji Kecocokan}

Penelitian ini menggunakan uji kecocokan Smirnov-Kolmogorov. Pengujian dilakukan dengan cara membandingkan probabilitas pada tiap-tiap variabel dari suatu distribusi yang hasilnya akan didapat perbedaan $(\Delta)$. Perbedaan maksimum ( $\Delta$ maks) yang dihitung dibandingkan dengan perbedaan kritis $(\Delta \mathrm{cr})$ untuk banyaknya varian tertentu. Sebaran dikatakan sesuai jika $\Delta_{\text {maks }}<\Delta_{\text {cr }}$ (Soewarno, 1995).

\section{Hujan Periode Ulang}

Penentuan hujan rancangan dapat dilakukan dengan analisis frekuensi. Analisis frekuensi digunakan untuk menentukan hujan rancangan dalam berbagai kala ulang berdasarkan distribusi yang paling sesuai antara distribusi hujan secara teoritik dengan distribusi hujan secara empirik. Kala ulang adalah waktu hipotetik dimana hujan dengan suatu besaran tertentu akan disamai atau dilampaui sekali dalam jangka waktu tersebut. Hujan periode ulang ini akan digunakan untuk menentukan intensitas hujan (Edy S, 2012). Pada penelitian ini, hujan periode ulang dihitung menggunakan Metode Log Pearson III dan Metode Gumbell. Hasil dari kedua metode ini dipilih nilai hujan periode ulang yang terbesar. 


\section{Waktu Konsentrasi Hujan}

Waktu konsentrasi adalah waktu yang diperlukan oleh air hujan yang jatuh untuk mengalir dari titik terjauh sampai tempat keluaran (titik kontrol) (Edy S, 2012). Penelitian ini menggunakan metode yang dikembangkan oleh Hathway (Ponce, 1989).

$\mathrm{t}_{\mathrm{c}}=\frac{0.606 \times(\mathrm{Ln})^{0.467}}{\mathrm{~S}^{0.234}}$

dengan:

tc : waktu konsentrasi (jam);

n : koefisien kekasaran;

L : panjang lintasan air $(\mathrm{km})$;

$\mathrm{S} \quad$ : kemiringan rata-rata saluran (m).

\section{Intensitas Hujan}

Intensitas hujan adalah ketinggian curah hujan yang terjadi pada suatu kurun waktu di mana air tersebut terkonsentrasi (Loebis, 1992). Penelitian ini menggunakan metode Mononobe, rumus Mononobe dapat dilihat pada Persamaan

$I_{t}=\frac{R_{24}}{t_{c}}\left[\frac{t_{c}}{t}\right]^{2 / 3}$

dengan:

It : Intensitas curah hujan pada jam ke- $\mathrm{t}(\mathrm{mm} / \mathrm{jam})$;

R24 : tinggi hujan rancangan dalam 24 jam (mm);

tc : waktu konsentrasi (jam);

t : jam ke-1 s/d jam ke- tc.

\section{Alternating Block Method (ABM)}

Alternating Block Method (ABM) adalah salah satu metode penentuan pola hujan jam-jaman dengan cara sederhana dengan membuat hyetograph rencana dari kurva Intensitas-Durasi-Frekuensi (IDF) (Chow et al., 1988). Hyetograph rencana yang dihasilkan oleh metode ini adalah hujan yang terjadi dalam $\mathrm{n}$ rangkaian interval waktu yang berurutan dengan durasi $\Delta \mathrm{t}$ selama waktu $\mathrm{Td}=\mathrm{n} \Delta \mathrm{t}$. Untuk periode ulang tertentu, intensitas hujan diperoleh dari kurva IDF pada setiap durasi waktu $\Delta \mathrm{t}, 2 \Delta \mathrm{t}, 3 \Delta \mathrm{t}, \ldots ., \mathrm{n} \Delta \mathrm{t}$. Ketebalan hujan diperoleh dari perkalian antara intensitas hujan dan durasi waktu tersebut. Perbedaan antara nilai ketebalan hujan yang berurutan merupakan pertambahan hujan dalam interval waktu $\Delta \mathrm{t}$.

\section{HSS SCS}

Hidrograf satuan merupakan suatu cara untuk memperkirakan penggunaan konsep hidrograf satuan dalam suatu perencanaan yang tidak tersedia pengukuran-pengukuran langsung mengenai hidrograf banjir (Lili Montarcih, 2010). Penelitian ini menggunakan Metode SCS yang dikembangkan oleh Victor Mockus (1950) untuk menghitung debit banjir yang terjadi.

Rumus yang digunakan dalam Metode SCS, sesuai dengan persamaan 3 sampai 10 berikut:

$\mathrm{S}=\frac{1000}{\mathrm{CN}}-10$

$\mathrm{Pe}=\frac{(\mathrm{P}-0,2 \times \mathrm{S})^{2}}{(\mathrm{P}+0,8 \times \mathrm{S})}$

$\mathrm{Tc}=0,39 \times \mathrm{L}^{0,77} \times \mathrm{S}^{-0,385}$

$\mathrm{Tp}=\frac{0,24 \times \mathrm{Tc}}{2}+\mathrm{tp}$

$\frac{\mathrm{T} 0}{\mathrm{Tp}}=\frac{\operatorname{Tr} \mathrm{x} T \mathrm{~T}}{\mathrm{Tp}}$

Dan untuk persamaan debit puncak:

$\mathrm{qp}=\frac{\mathrm{A}}{\mathrm{T} 0 \text { terkoreksi }} \times 484$

$\mathrm{Qp}=\mathrm{qp} \times \mathrm{Pe} \times 0,028$

(Ponce. 1989)

dengan:

$\mathrm{S} \quad$ : infiltrasi maksimum yang mungkin terjadi $(\mathrm{cm})$;

$\mathrm{CN}$ : curve number;

$\mathrm{P} \quad$ : kedalaman hujan $(\mathrm{mm})$;

$\mathrm{Pe} \quad$ : kedalaman hujan efektif (mm);

L : panjang sungai $(\mathrm{km})$;

A : luas area $(\mathrm{km} 2)$;

Tc : waktu konsentrasi (menit);

Tp : waktu puncak (jam); 
$\operatorname{Tr} \quad$ : satuan durasi hujan (jam);

qp : debit punca (m3/detik);

Qp : debit puncak limpasan (m3/detik).

\section{Tinggi Muka Air Banjir}

Tinggi muka air banjir adalah elevasi muka air saat terjadi banjir. TMA banjir dicari guna mengetahui bagaimana keadaan struktur PLTS pada saat terjadi banjir. Rumus yang digunakan dalam mencari TMA banjir adalah rumus tinggi energi-debit yang ada pada KP-02 halaman 95.

$\mathrm{Q}_{\text {rencana }}=\mathrm{C}_{\mathrm{d}} \times \frac{2}{3} \times \sqrt{\frac{2}{3} \times \mathrm{g} \times \mathrm{B}} \times\left(\mathrm{H}_{\text {limpasan }}-\mathrm{H}_{\text {mercu }}\right)^{\frac{3}{2}}$

(KP-02, halaman 95)

dengan:

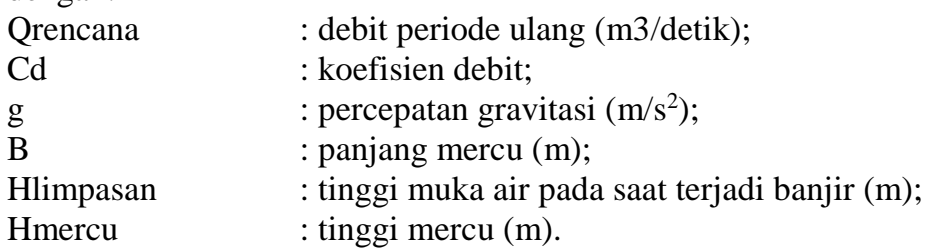

\section{Luas Genangan Waduk}

Luas genangan waduk merupakan luas permukaan waduk secara keseluruhan pada elevasi muka air tertentu. Luas genangan waduk dihitung berdasarkan data volume waduk pada berbagai elevasi dan menggunakan rumus volume sebagai berikut:

$\Delta \mathrm{V}=$ luas genangan $\times \Delta \mathrm{TMA}$

dengan:

$\Delta \mathrm{V} \quad$ : selisis volume waduk pada muka air rencana dan pada muka air diatas rencana $(\mathrm{m} 3)$;

Luas genangan $\quad$ : luas genangan waduk pada elevasi rencana $(\mathrm{m} 2)$;

$\triangle T M A \quad:$ selisih tinggi muka air rencana dan tinggi muka air diatas rencana $(\mathrm{m})$

\section{Luas Genangan Ijin}

Luas genangan ijin merupakan luas permukaan waduk yang diperbolehkan untuk dibangun struktur diatasnya. Luas permukaan waduk ditentukan berdasarkan tinggi muka air yang paling sering terjadi di Waduk Bening/ Widas. Luas genangan ijin didapatkan dari perhitungan luas permukaan waduk secara keseluruhan dikurangi dengan luas permukaan waduk yang digunakan untuk penempatan instrumen dan luas permukaan waduk yang dilarang untuk dibangun struktur diatasnya. Luas genangan ijin ini nantinya akan digunakan sebagai acuan dalam menentukan seberapa luas PLTS yang akan dirancang diatas waduk.

\section{Pembangkit Listrik Tenaga Surya}

Dalam cahaya matahari terkandung energi dalam bentuk foton. Ketika foton ini mengenai permukaan sel surya, elektron-elektronnya akan tereksitasi dan menimbulkan aliran listrik. Prinsip ini dikenal sebagai prinsip photoelectric. Sel surya ini mudah pecah dan berkarat jika terkena air. Karena itu sel ini dibuat dalam bentuk panel-panel ukuran tertentu yang dilapisi plastik atau kaca bening yang kedap air. Panel ini dikenal sebagai panel surya (Anya P D, 1997). Energi radiasi matahari dirubah menjadi energi listrik dengan mempergunakan pembangkit listrik tenaga surya atau disebut juga teknologi photovoltaic yang terbuat dari bahan semi konduktor lainnya, yang disebut solar cell.

\section{Daya dan Energi PLTS}

Daya adalah banyaknya energi yang diperlukan tiap satuan waktu. Tiap-tiap panel surya akan menghasilkan daya dengan besaran tertentu pada puncak penyinaran matahari. Besaran nilai daya yang dikeluarkan tergantung dari produk yang digunakan. Pada penelitian ini, daya yang dihasilkan oleh 1 panel surya pada puncak penyinaran matahari adalah sebesar $250 \mathrm{Wp}$.

Energi listrik yang dihasilkan PLTS inilah yang akan dijual ke PT. PLN dan digunakan guna memenuhi kebutuhan listrik negara. Besar kecilnya energi yang dihasilkan tergantung dari radiasi surya pada wilayah tersebut. Untuk wilayah Madiun, radiasi surya sebesar $4,4 \mathrm{kWh} / \mathrm{kWp}$. Rumus yang digunakan untuk menghitung energi adalah sebagai berikut:

$\mathrm{E}=\mathrm{P} \times$ radiasi surya

dengan:

$\begin{array}{ll}\mathrm{E} & \text { : energi listrik PLTS }(\mathrm{kWh}) ; \\ \mathrm{P} & \text { : daya } \mathrm{AC}(\mathrm{kWp})\end{array}$

Radiasi surya : konstanta (kWh/kWp). 


\section{Software Geo-Slope}

Program Geo-slope adalah sebuah paket aplikasi untuk pemodelan geoteknik dan geo-lingkungan. Software ini melingkupi Slope/w, Seep/w, Sigma/w, Quake/w, Tempt/w dan Ctran/w. Slope/w merupakan produk perangkat lunak untuk menghitung faktor keamanan lereng dan kemiringan batuan. Slope/w Define merupakan program yang digunakan untuk pemodelan permasalahan lereng dalam bentuk penggambaran pada layar komputer dalam aplikasi Computer Aided Design (CAD). Kemudian data yang telah dimodelkan tersebut dianalisis dengan menggunakan Slope/w Solve. Perhitungan dilakukan sesuai dengan data masukan dan pengaturan analisis (Analysis Setting) yang telah ditentukan. Slope/w Contour akan menampilkan grafis seluruh bidang longsor dan nilai faktor aman dapat ditunjukkan dalam bentuk kontur faktor aman serta diagram dan poligon tiap pias tertentu (Uswatun C, 2012).

\section{METODE PENELITIAN}

Metode penelitian yang dilakukan adalah analisis matematis dan software dengan melakukan perhitungan ruang/ kapasitas waduk, luas desain PLTS, dan pengaruh adanya PLTS terhadap keamanan bendungan di waduk Bening/ Widas dengan pemodelan pada software Geo-Slope.

Tahapan penelitian ini dimulai dengan pengumpulan data. Data yang digunakan dalam penelitian ini adalah data sekunder. Data hujan diperoleh dari Dinas Pekerjaan Umum dan Penataan Ruang Kabupaten Madiun. Data tinggi muka air, data volume tampungan, data teknis Waduk Bening/Widas diperoleh dari Divisi Hidroinformatika, Perum Jasa Tirta I (PJT), Malang. Data produk didapatkan dari pencarian di internet. File .shp hidrografi dan hipsografi Kabupaten Madiun diperoleh dari Badan Informasi Geospasial (BIG).

Setelah data terkumpul, maka dilakukan pembuatan peta topografi dan peta stasiun hujan. Peta stasiun hujan, peta topografi dan perhitungan panjang sungai dilakukan dengan software Arc GIS 10.3. Tahapan selanjutnya adalah analisis hidrologi yang dilakukan dengan software Microsoft Excel. Dalam analisis hidrologi, data hujan yang digunakan adalah data hujan Stasiun Catur, Stasiun Gemarang, dan Stasiun Saradan. Output utama dari analisis hidrologi adalah tinggi muka air banjir dengan kala ulang 200 tahun dan 1000 tahun.

Tahapan selanjutnya adalah analisis ruang waduk. Data yang digunakan adalah data tinggi muka air, data volume tampunga, dan peta tampak atas Waduk Bening/Widas. Dalam analisis ruang waduk, dicari luas genangan Waduk Bening/Widas. Setelah luas genangan didapatkan, maka dengan beberapa pertimbangan dapat ditentukan luas genangan ijin $\left(\mathrm{L}_{\mathrm{gi}}\right)$. Luas genangan ijin inilah yang digunakan sebagai dasar penentuan luas desain PLTS.

Jika luas desain sudah ditentukan, maka dilakukan analisis keamangan bendungan dengan software Geo-Slope modul Slope-W. Analisis ini dilakukan dengan tujuan untuk mengetahui masih amankah bendungan dengan adanya penambahan struktur PLTS di waduk. Setelah itu, barulah dilakukan analisis daya dan energi PLTS berdasarkan luas desain tersebut. Analisis ini dilakukan untuk mengetahui berapa energi yang dihasilkan oleh PLTS dalam 1 tahun.

\section{HASIL DAN PEMBAHASAN}

\section{Analisis Hidrologi dan Tinggi Muka Air Banjir}

Analisis hidrologi dilakukan untuk mengetahui nilai debit banjir kala ulang 200 tahun dan 1000 tahun. Hasil perhitungan menunjukkan nilai debit banjir kala ulang 200 tahun $\left(\mathrm{Q}_{\text {maks }}\right)$ adalah $228,778 \mathrm{~m} 3 / \mathrm{detik}$, dan kala ulang 1000 tahun $\left(\mathrm{Q}_{\text {maks }}\right)$ adalah 277,338 m³/detik. Hasil perhitungan hidrograf banjir dapat dilihat pada Gambar 1 .

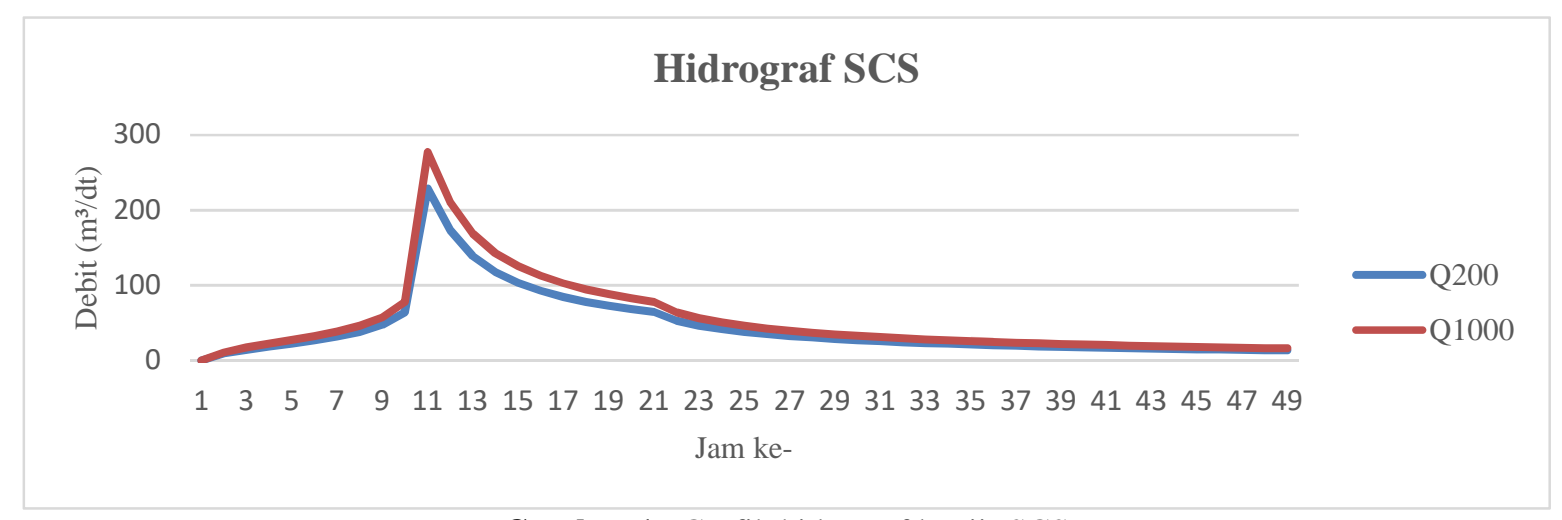

Gambar 1. Grafik hidrograf banjir SCS 
Perhitungan tinggi muka air banjir dipengaruhi oleh koefisien bendung dan lebar mercu. Berdasarkan rumus dari KP-02, hal 42, tinggi muka air banjir kala ulang 200 tahun terjadi pada elevasi 110,3573 m dengan tinggi jagaan $1,243 \mathrm{~m}$. Tinggi muka air banjir kala ulang 1000 tahun terjadi pada elevasi 110,598 m dengan tinggi jagaan 1,002 $\mathrm{m}$.

\section{Analisis Luas Genangan Ijin $\left(\mathbf{L}_{\mathrm{g}}\right)$}

Analisis luas genangan ijin dilakukan untuk mengetahui berapa luas genagan yang diijinkan adanya struktur PLTS di Waduk Bening/Widas. Setelah dilakukan perhitungan, didapatkan hasil luas genangan di Waduk Bening/Widas adalah $4196240 \mathrm{~m}^{2}$. Namun, tidak semua luas genangan bisa dijadikan sebagai tempat peletakan struktur PLTS, dikarenakan adanya instrumen-instrumen pengukuran waduk yang terpasang, adanya beberapa area yang dilarang berdirinya struktur diatas area tersebut, dan adanya area yang digunakan untuk wisata air. Oleh sebab itu, harus ditentukan luas genangan ijin. Luas genangan ijin ditentukan dengan cara digitasi melalui software Auto-CAD, sehingga didapatkan hasil luas genangan ijin ( $\mathrm{Lgi}_{\text {gi }}$ sebesar $944893 \mathrm{~m}^{2}$. Luas genangan ijin bisa dilihat pada Gambar 2. Pada Gambar 2, luas genangan ijin $\left(\mathrm{L}_{\mathrm{gi}}\right)$ ditunjukkan dengan area yang diarsir, sedangkan area yang tidak diarsir merupakan area yang dilarang adanya bangunan struktur diatas dan area wisata air. Gambar 2 ditunjukkan dengan Gambar dibawah ini.

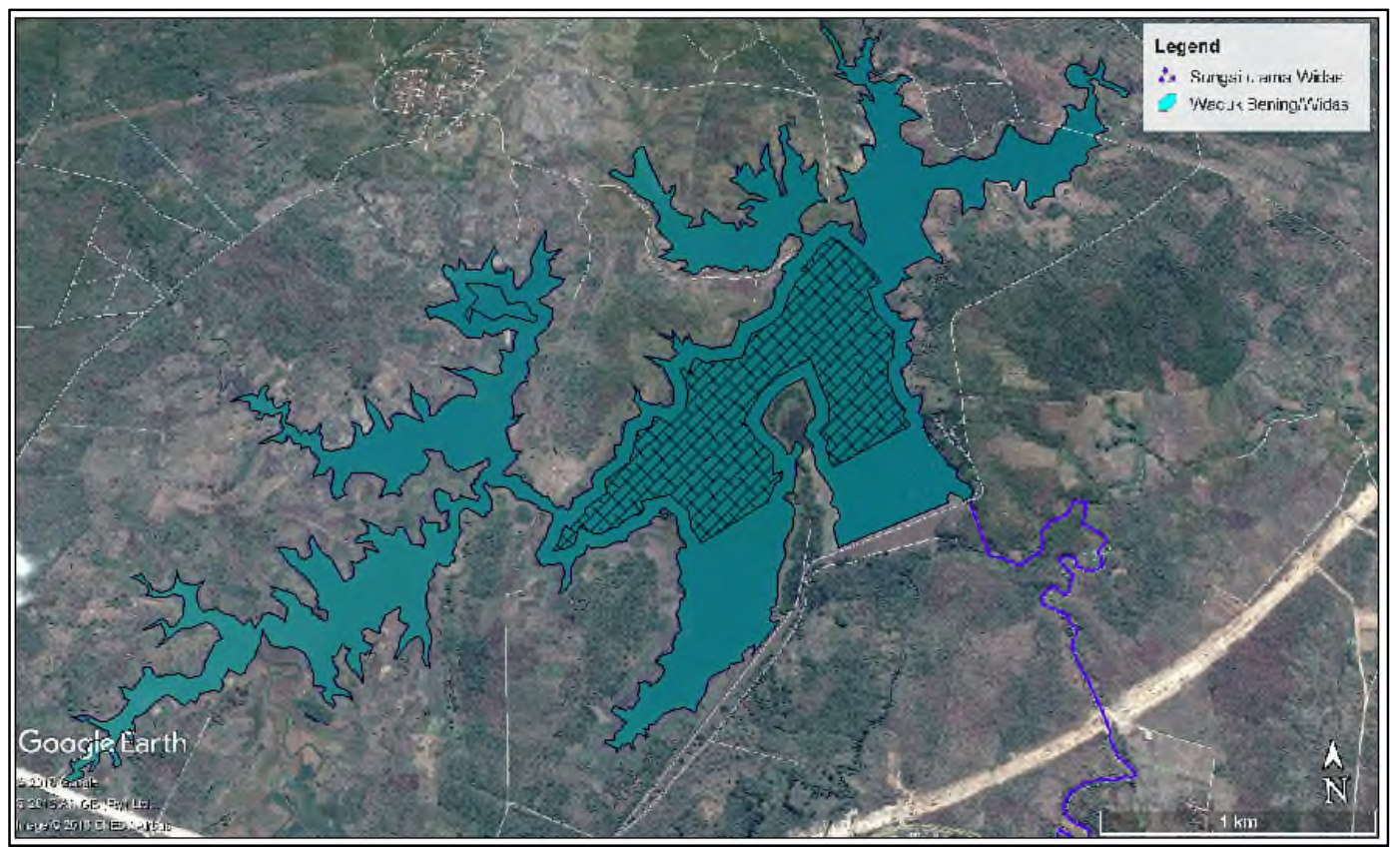

Gambar 2. Luas genangan ijin di Waduk Bening/Widas

\section{Daya dan Energi PLTS}

PLTS didesain dengan mempertimbangkan luas genangan ijin. Pada penelitian ijin didesain 1 modul PLTS terdiri dari 2500 panel surya, 2601 unti poonton, dan 11-unit inverter. Ruang yang dibutuhkan untuk 1 modul PLTS adalah sebesar $8000 \mathrm{~m}^{2}$. Telah diketahui luas genangan ijin sebesar $944893 \mathrm{~m}^{2}$ dan luas 1 modul PLTS adalah $8000 \mathrm{~m}^{2}$, sehingga jumlah modul PLTS yang didesain adalah 20 modul.

Perhitungan daya PLTS dilakukan berdasarkan daya maksimum yang bisa dihasilkan oleh 1 modul surya. Setelah dilakukan perhitungan, didapatkan hasil 1 modul PLTS dapat menghasilkan $625 \mathrm{kWp}$ (DC). Daya DC harus diubah menjadi daya AC dengan alat inverter. Karena adanya efisiensi dari inverter sebesar 98,8\%, maka daya AC yang dihasilkan oleh 1 modul PLTS adalah 612,34 kWp.

Setelah daya AC diketahui, maka dapat dilakukan perhitungan energi dengan mengalikan daya AC dengan nilai radiasi surya. Radiasi surya untuk daerah Kabupaten Madiun adalah sebesar 4,4 kWh/kWp, sehingga didapatkan energi sebesar 2,69 MWh/hari. Energi yang dihasilkan oleh 1 modul PLTS dalam 1 tahun adalah sebesar 983,43 MWh, sehingga energi yang dihasilkan oleh 20 modul PLTS dalam 1 tahun adalah sebesar 19668,52 MWh.

\section{Analisis Faktor Aman}

Analisis faktor aman dilakukan dengan memodelkan Bendungan Bening/Widas dengan software Geo-Slope modul Slope-W. Didapatkan nilai faktor aman bendungan dengan berbagai kondisi seperti yang disajikan dalam Tabel 1. 
Tabel 1. Nilai faktor aman bendungan hasil analisis software Geo-Slope

\begin{tabular}{lc}
\hline \multicolumn{1}{c}{ Kondisi } & Faktor Aman \\
\hline Tanpa muka air & 2,549 \\
Muka air rendah & 2,532 \\
Muka air tinggi & 2,632 \\
Muka air banjir Q 200 & 3,202 \\
Muka air banjir Q ${ }_{1000}$ & 3,192 \\
Muka air rencana & 2,606 \\
Struktur PLTS menempel pada tubuh bendungan & 2,971 \\
Struktur PLTS menabrak pada tubuh bendungan & 3,192 \\
\hline
\end{tabular}

Nilai aman bendungan pada umumnya adalah 1,5. Analisis yang dilakukan didapatkan nilai faktor aman diatas 1,5 sehingga dengan bendungan Bening/Widas tetap aman walaupun ada penambahan beban akibat struktur PLTS.

\section{KESIMPULAN}

Kesimpulan dari penelitian ini adalah sebagai berikut :

1. Luas genangan pada Waduk Bening/Widas adalah $4196240 \mathrm{~m}^{2}$ sedangkan luas genangan ijin ( $\mathrm{L}_{\text {gi }}$ ) pada Waduk Bening/Widas adalah $944893 \mathrm{~m}^{2}$ atau sebesar $22.52 \%$ dari luas genangan. Dengan luas genangan ijin tersebut, dapat diapungkan 20 modul PLTS.

2. Daya yang dihasilkan oleh 1 modul PLTS adalah $612,34 \mathrm{kWp}$ dan nilai energi yang dihasilkan oleh 1 modul PLTS adalah 2,69 MWh/hari, sehingga jika dibangun 20 modul PLTS akan dihasilkan energi sebesar 19668,52 MWh dalam 1 tahun.

\section{REKOMENDASI}

1. Lebih memperhatikan kesiapan data, agar dalam analisis dan perhitungan tidak terlalu banyak menggunakan pendekatan dan asumsi.

2. Lebih memperdalam pengetahuan mengenai PLTS, sehingga tepat dan benar dalam melakukan analisis daya dan energi.

3. Melakukan analisis faktor aman yang lebih detail dan terperinci.

4. Melakukan analisis ekonomi teknik yang lebih detail dan terperinci.

\section{UCAPAN TERIMAKASIH}

Ucapan terima kasih pertama ditujukan kepada Allah SWT atas limpahan rahmat dan nikmatnya. Selanjutnya kepada Dr. Ir. Rr. Rintis Hadiani, M.T. dan Ir. Solichin, M.T. selaku dosen pembimbing yang telah memberi arahan dan masukan dalam penelitian ini.

\section{REFERENSI}

Chasanah, Uswatun. 2012. Analisis Stabilitas Lereng dengan Perkuatan Geotekstil menggunakan Program GEOSLOPE. Universitas Sebelas Maret. Surakarta

Chow, V.T., Maidment, D.R., and Mays, L.W. 1988. Applied Hydrology. McGraw-Hill. Singapore.

Damastuti, Anya P. 1997. Pembangkit Listrik Tenaga Surya. Wacana Nomor 7. Maret - April 1997

Direktorat Jenderal Pengairan. Kriteria Perencanaan Bagian Bangunan Utama KP-02

Hasan, Hasnawiya. 2012. Perancangan Pembangkit Listrik Tenaga Surya di Pulau Saugi. Jurnal Riset dan Teknologi Kelautan (JRTK). Volume 10, Nomor 2, Juli - Desember 2012

Loebis, Joesron. 1993. Hidrologi Sungai. Badan Penerbit PU. Jakarta

Ponce, Victor Miguel. 1989. Engineering Hydrology : Principles and Practices. Prentice Hall Inc. New Jersey, United States of America.

Santhiarsa; I Gusti Ngurah Nitya; I Gusti Bagus Wijawa Kusuma. 2005. Kajian Energi Surya untuk Pembangkit Tenaga Listrik. Teknologi Elektro. Volume 4, Nomor 1, Januari - Juni 2005

Soewarno. 1995. Hidrologi Aplikasi Metode Statistik Jilid 1. Nova. Bandung

Soewarno. 1995. Hidrologi Aplikasi Metode Statistik Jilid 2. Nova. Bandung

Sriyono, Edy. 2012. Analisis Debit Banjir Rancangan Rehabilitasi Situ Sidomukti. Jurnal Teknik. Vol. 2 No. 2 /

Oktober 2012 